\title{
Glucanolytic Actinomycetes Antagonistic to Phytophthora fragariae var. rubi, the Causal Agent of Raspberry Root Rot
}

\author{
DIANE VALOIS, ${ }^{1}$ KARINE FAYAD,${ }^{1}$ THARCISSE BARASUBIYE,${ }^{1}$ MARIE GARON, ${ }^{2}$ \\ CLAUDE DÉRY, ${ }^{1}$ RYSZARD BRZEZINSKI, ${ }^{1}$ AND CAROLE BEAULIEU ${ }^{1 *}$ \\ Groupe de Recherche en Biologie des Actinomycètes, Département de Biologie, Université de Sherbrooke, \\ Sherbrooke, Québec, Canada J1K 2R1, ${ }^{1}$ and Service de Phytotechnie de Québec, \\ Ministére de l'Agriculture des Pêcheries et de l'Alimentation du Québec, \\ Sainte-Foy, Québec, Canada G3P $3 W 8^{2}$
}

Received 23 October 1995/Accepted 10 February 1996

\begin{abstract}
A collection of about 200 actinomycete strains was screened for the ability to grow on fragmented Phytophthora mycelium and to produce metabolites that inhibit Phytophthora growth. Thirteen strains were selected, and all produced $\beta-1,3-, \beta-1,4-$, and $\beta-1,6$-glucanases. These enzymes could hydrolyze glucans from Phytophthora cell walls and cause lysis of Phytophthora cells. These enzymes also degraded other glucan substrates, such as cellulose, laminarin, pustulan, and yeast cell walls. Eleven strains significantly reduced the root rot index when inoculated on raspberry plantlets.
\end{abstract}

Actinomycetes represent a high proportion of the soil microbial biomass (2). They have the capacity to produce a wide variety of extracellular hydrolases (15) that give them an important role in the decomposition of organic matter in the soil. In addition to their active function in decomposition, actinomycetes appear to be of importance among the microbial flora of the rhizosphere. Indeed, the last few years have seen different aspects of plant-actinomycete interactions studied extensively. Associations between actinomycetes and underground plant organs could be deleterious or beneficial for the plants. While some actinomycetes secrete herbicidal compounds (39) or cause diseases such as pox and common scab (22), others can symbiotically fix atmospheric nitrogen (4) or protect roots against fungal infections (44).

Actinomycete-fungus antagonism has been demonstrated for a wide variety of plant pathogens, such as Alternaria (9), Rhizoctonia (26, 35), Verticillium (42), Fusarium (36), and Macrophomina (17) spp. Moreover, actinomycetes of the genus Streptomyces have been used to commercially control plant diseases. For example, Streptomyces sp. strain 5406 has been used in China for more than 30 years now to protect cotton crops against soil-borne pathogens (46). More recently, Kemira Oy has developed a biofungicide that contains living Streptomyces griseoviridis cells to protect crops against Fusarium and Alternaria infections (20).

Evidence that diseases caused by fungus-like protoctistan Phytophthora and Pythium species can also be controlled by actinomycetes has accumulated. Broadbent et al. (8) and Knauss (19) have established that numerous streptomycetes can inhibit the growth of Pythium and Phytophthora spp. through the production of antibiotics. Furthermore, several experiments demonstrated that soil inoculation with specific streptomycete strains could significantly reduce damage caused by Pythium or Phytophthora species in ornamental $(6,7,24,47)$, legume (13), and horticultural $(11,38,41)$ productions.

Phytophthora spp. were identified as causal agents of raspberry root rot in Canada for the first time in 1988 (40). Simi-

\footnotetext{
* Corresponding author. Mailing address: Département de Biologie, Université de Sherbrooke, Sherbrooke, Québec, Canada J1K 2R1. Phone: (819) 821-7997. Fax: (819) 821-8049. Electronic mail address: C.BEAULI@COURRIER.USHERB.CA.
}

larly, Phytophthora has also been associated with raspberry root rot in Australia (43), Chile (21), Europe (12, 27, 30), and the United States (45). In Canada, metalaxyl is the only authorized product to control Phytophthora disease in raspberry crops. Unfortunately, it has been demonstrated that Phytophthora fragariae can develop resistance against metalaxyl (29). Therefore, the ultimate goal of our research program is to develop a biocontrol method of root rot in raspberry crops.

The purposes of this study are (i) to propose a method based on the ability of actinomycetes to produce antifungal metabolites as well as glycosyl hydrolases for selecting biocontrol candidates, (ii) to verify the ability of the selected strains to protect raspberry roots against $P$. fragariae var. rubi, and (iii) to partially characterize the glucanolytic activity of the selected biocontrol agents.

\section{MATERIALS AND METHODS}

Culture conditions. $P$. fragariae var. rubi ML200 was usually grown at $22^{\circ} \mathrm{C}$ on V8 medium (33) or potato dextrose agar (PDA). Actinomycetes were maintained on YGM+ (18). A minimal medium (16) supplemented with different glucan sources at $0.5 \%$ and $0.1 \%$ yeast extract was used to assay the glucanolytic activity of the actinomycetes. The mycelium agar used to select biocontrol agents and to visualize glucanolytic activity was prepared as follows. $P$. fragariae var. rubi ML200 was grown in $25 \mathrm{ml}$ of V8 broth for 7 days at $22^{\circ} \mathrm{C}$. This culture was then autoclaved and centrifuged, and the pellet was rinsed three to four times with sterile water. The mycelium was then resuspended in $25 \mathrm{ml}$ of sterile water and fragmented with a French press $\left(12,000 \mathrm{lb} / \mathrm{in}^{2}\right)$. Three volumes of sterile water and agar at a concentration of $1.5 \%$ were then added to the fragmented mycelium suspension. The resulting mycelium agar was sterilized.

Screening of antagonistic actinomycetes. About 200 nonphytopathogenic actinomycete strains which were isolated from raspberry roots, potato rhizosphere, or soil were tested for their ability to grow and to produce clear zones on mycelium agar at $15^{\circ} \mathrm{C}$. Actinomycete strains producing clear zones on mycelium agar were then analyzed for their activity against Phytophthora spp. at $15^{\circ} \mathrm{C}$. For the antifungal activity test, actinomycetes were inoculated onto a V8 plate. A piece $\left(1 \mathrm{~cm}^{2}\right)$ of V8 agar bearing a 14-day-old $P$. fragariae culture was inoculated $2 \mathrm{~cm}$ from the actinomycete inoculation spot. Zones of growth inhibition were recorded after 10 days of incubation. Actinomycete strains exhibiting production of both clear zones on mycelium agar and metabolites against the Phytophthora strain were considered antagonistic and were used in the biocontrol assay.

Biocontrol assay. In vitro-produced raspberry plantlets (cultivar Heritage; five-leaf stage) were planted in 12-cm-diameter pots containing sterilized loamy soil and grown for 14 days before bacterial inoculation. Ten plantlets were individually inoculated with each antagonistic actinomycete. Two control sets of 10 raspberry plantlets each were not inoculated.

Bacterial inocula were prepared by growing actinomycetes in YGM+ for $24 \mathrm{~h}$ at $30^{\circ} \mathrm{C}$. A fraction of each culture $(1 \mathrm{ml})$ was spread on a YME (32) plate, and the plates were incubated until sporulation occurred. Three pieces $(10-\mathrm{mm}$ 
TABLE 1. Actinomycete strains used in this study ${ }^{a}$

\begin{tabular}{|c|c|c|c|}
\hline Strain(s) & Source & $\begin{array}{l}\text { Phytophthora growth } \\
\text { inhibition }\end{array}$ & $\begin{array}{l}\text { Clearing zone produced } \\
\text { on mycelium agar }\end{array}$ \\
\hline EF-36, EF-39, EF-91, EF-94, EF-96 & Potato rhizosphere & + & - \\
\hline $\begin{array}{l}\text { EF-6, EF-13, EF-16, EF-17, EF-18, EF-29, EF-37, EF-45, } \\
\text { EF-100, EF-101, EF-105, EF-117, EF-119 }\end{array}$ & Potato rhizosphere & - & + \\
\hline DVX2, DVX3 & Soil from raspberry plantation & - & + \\
\hline $\begin{array}{l}\text { EF-14, EF-22, EF-25, EF-27, EF-34, EF-43, EF-72, } \\
\text { EF-76, EF-97 }\end{array}$ & Potato rhizosphere & + & + \\
\hline DVD1, DVD3, DVD4 & Soil from raspberry plantation & + & + \\
\hline N106 & Soil from maple grove & + & + \\
\hline
\end{tabular}

${ }^{a}$ Strains producing no clear zone on mycelium agar and no inhibition of Phytophthora growth on V8 agar are not included in this table.

diameter) were cut from the agar cultures and set around the developing roots of each plantlet.

One week after bacterial inoculation, $P$. fragariae var. rubi ML200 was inoculated into the soil by the method of Nourrisseau and Baudry (30). Three pieces (10-mm diameter) were cut from Phytophthora cultures on V8 agar and added to the soil of raspberry plantlets infested by antagonistic actinomycetes. One set of raspberry plants was inoculated with $P$. fragariae (positive control), while another set was not (negative control). The plantlets were then incubated for 8 additional weeks and kept at $15^{\circ} \mathrm{C}$ on a 12 -h photoperiod. Raspberry plantlets were sprayed with water every day, while the soil was kept constantly wet.

The severity of symptoms was recorded with a disease index ranging from 0 to 5 (24), where 0 represents a healthy plantlet and 5 represents a plantlet with chlorosis and necrosis on more than $80 \%$ of the surface of the leaves and the roots.

Glucanolytic activities in culture supernatants of antagonistic actinomycetes. The ability of antagonistic actinomycetes to produce $\beta$-1,3-glucanases, $\beta$-1,4glucanases, and $\beta-1,6$-glucanases was tested in a minimal medium supplemented with laminarin (Sigma), cellulose (Fluka), and pustulan (Calbiochem), respectively. To assay $\beta$-1,4-glucanase activity, $250 \mu$ l of cellulose suspension $(2.5 \mathrm{mg}$ of cellulose per $\mathrm{ml}$ in $50 \mathrm{mM}$ acetate buffer, $\mathrm{pH} 5.5$ ) was mixed with culture supernatant and water to a final volume of $500 \mu \mathrm{l}$. The mixture was kept at $37^{\circ} \mathrm{C}$ for $1 \mathrm{~h}$. The reaction was stopped by adding the first reagent for reducing sugar determination. The amount of reducing sugars released was determined by the Nelson-Somogyi procedure (37). $\beta-1,3$ - and $\beta$-1,6-glucanases were assayed in the same way except that laminarin and pustulan were used as the substrate, respectively. The incubation with laminarin and pustulan dissolved in $50 \mathrm{mM}$ phosphate-citrate, $\mathrm{pH} 7.0$, lasted for $15 \mathrm{~min}$ at $50^{\circ} \mathrm{C}$. One unit of glucanase activity was defined as the amount of enzyme that releases $1 \mu \mathrm{mol}$ of reducing sugar per min in these conditions.

Chromatographic profile of glucanases produced by the actinomycete EF-14. Spores of EF-14 were inoculated into a medium containing (per liter) $8 \mathrm{~g}$ of yeast extract, $6 \mathrm{~g}$ of malt extract, $0.5 \mathrm{~g}$ of $\mathrm{K}_{2} \mathrm{HPO}_{4} \cdot 2 \mathrm{H}_{2} \mathrm{O}$, and $0.5 \mathrm{~g}$ of anhydrous $\mathrm{KH}_{2} \mathrm{PO}_{4}, \mathrm{pH} 6.5$. After $24 \mathrm{~h}$ of incubation at $30^{\circ} \mathrm{C}$, the mycelium was collected by centrifugation and washed with sterile $0.9 \% \mathrm{NaCl}$. A portion $(1 \mathrm{ml})$ of the mycelium wet pellet was then inoculated into $100 \mathrm{ml}$ of glucanase induction medium containing minimal salts $(28)$ and $7.5 \mathrm{~g}$ (wet weight) of mycelium of $P$. fragariae var. rubi ML200. After $48 \mathrm{~h}$ of incubation at $30^{\circ} \mathrm{C}$, the supernatant was collected by centrifugation. A portion $(10 \mathrm{ml})$ of the supernatant was loaded onto a Sephacryl S-100 column $(1.6$ by $100 \mathrm{~cm})$ previously equilibrated with 50 $\mathrm{mM}$ potassium acetate, $\mathrm{pH}$ 5.5. Fractions $(5 \mathrm{ml})$ were collected, and glucanase activities were assayed in paired fractions for the capacity to release reducing sugars from the appropriate substrates.

Lytic activity assays. For estimation of lytic activity, a suspension of yeast cell walls was prepared as described by Rombouts et al. (34). Fractions from the chromatographic column $(0.4 \mathrm{ml})$ were combined with $0.1 \mathrm{ml}$ of yeast cell wall suspension and $0.5 \mathrm{ml}$ of $50 \mathrm{mM}$ potassium acetate buffer (pH 5.5). This mixture was incubated with continuous rotation at $30^{\circ} \mathrm{C}$ for $18 \mathrm{~h}$, and then absorbance was measured at $450 \mathrm{~nm}$. The lytic activity was calculated as described by Rombouts et al. (34).

The lytic activity of glucanases was also qualitatively verified on live Phytophthora cells. Extracellular glucanases were obtained by growing Streptomyces sp. strain EF-14 in mycelium broth for $72 \mathrm{~h}$. The culture supernatant was collected by centrifugation. The supernatant was then dialyzed overnight against distilled water, and the $\beta-1,3$-glucanase activity of the supernatant was measured as described above. The Phytophthora mycelium used for the lytic test was obtained from 4-day-old V8 broth cultures. Phytophthora cultures were centrifuged, and the pellet was washed twice with distilled water. Crude enzyme solutions containing $1.5,3.0$, and $6.0 \mathrm{U}$ of $\beta-1,3$-glucanases per $\mathrm{ml}$ were added to $50 \mathrm{mg}$ of mycelium (wet weight) and incubated for $150 \mathrm{~min}$ at $22^{\circ} \mathrm{C}$. The lytic assay on Phytophthora mycelium was carried out in triplicate.

\section{RESULTS}

Selection of antagonistic actinomycetes. Actinomycete strains exhibiting the ability to produce both clear zones on mycelium agar and metabolites against the Phytophthora strain on V8 agar were considered antagonistic (Table 1). A relatively high proportion (14\%) of the 200 actinomycetes tested produced clear zones on mycelium agar. A smaller proportion of the actinomycete collection (6.5\%) exhibited both properties, growth on mycelium agar and inhibition of Phytophthora growth. These antagonistic bacteria originated from potato rhizosphere (nine isolates) and from soil (four isolates). None of the actinomycete strains isolated from healthy or infested raspberry roots were found to be antagonistic.

Biocontrol assay. Antagonistic strains were tested for their ability to protect raspberry plantlets against Phytophthora infections. Most of the antagonistic actinomycetes protected raspberry plantlets, but the level of protection varied among the antagonistic strains. Five of these antagonistic strains (EF72, EF-22, EF-34, EF-14, and EF-97) reduced disease symptoms (measured by the root rot index) to levels that could not be significantly distinguished from those of the uninfected raspberry plants, the negative controls (Table 2). Six other actinomycete strains (EF-76, EF-27, EF-43, DVD3, EF-25, and DVD4) were less efficient as biocontrol agents, even though they still caused a significant reduction in the severity of the symptoms. Indeed, the root rot index was decreased from 4.98 in the positive controls (raspberries inoculated only with the pathogenic Phytophthora strain) to 2.67 to 3.22 for the plants treated with these six actinomycetes. Inoculation of raspberry roots with the remaining two antagonistic strains, N106 and DVD1, did not significantly reduce the severity of the symptoms caused by $P$. fragariae var. rubi (Table 2).

Glucanolytic activity associated with antagonistic bacteria. All of the antagonistic actinomycetes produced $\beta-1,3-, \beta-1,4-$, and $\beta-1,6$-glucanases when grown on laminarin, cellulose, and pustulan, respectively. However, glucanolytic activities varied considerably among the isolates, ranging from 0.015 to 2.21 $\mathrm{U} / \mathrm{ml}$ for $\beta-1,3$-glucanases and from 0.001 to $0.035 \mathrm{U} / \mathrm{ml}$ for $\beta$-1,4-glucanases. The difference in $\beta, 1-6$-glucanase production was less pronounced, ranging from 0.072 to $0.109 \mathrm{U} / \mathrm{ml}$ (Table $3)$. The glucanases secreted by the antagonistic actinomycetes also efficiently degraded glucans from Phytophthora cell walls, 
TABLE 2. Effect of bacterial inoculation on root rot caused by $P$. fragariae var. rubi ML200

\begin{tabular}{|c|c|}
\hline Inoculum & $\begin{array}{l}\text { Root rot } \\
\text { index }\end{array}$ \\
\hline None $(\text { control })^{b}$. & $.0 .89 \mathrm{a}$ \\
\hline ML200 + actinomycete EF-72. & $63 \mathrm{ab}$ \\
\hline ML200 + actinomycete EF-22. & $.1 .67 \mathrm{ab}$ \\
\hline ML200 + actinomycete EF-34. & $.2 .25 \mathrm{ab}$ \\
\hline ML200 + actinomycete EF-14. & $.2 .56 \mathrm{abc}$ \\
\hline ML200 + actinomycete EF-97. & $.2 .56 \mathrm{al}$ \\
\hline ML200 + actinomycete EF-76. & $.2 .67 \mathrm{bc}$ \\
\hline ML200 + actinomycete EF-27. & $.2 .78 \mathrm{bc}$ \\
\hline ML200 + actinomycete EF-43. & $.3 .11 \mathrm{bc}$ \\
\hline ML200 + actino & $.3 .11 \mathrm{bc}$ \\
\hline ML200 + actinor & $.3 .22 \mathrm{bc}$ \\
\hline ML200 + actinomycete DVD4 & $.3 .22 \mathrm{bc}$ \\
\hline ML200 + actinomycete N106... & $.3 .33 \mathrm{~cd}$ \\
\hline ML200 + actinomycete DVD1 & $.4 .22 \mathrm{~cd}$ \\
\hline & $.4 .98 \mathrm{~d}$ \\
\hline
\end{tabular}

${ }^{a}$ Index values accompanied by the same letter do not differ significantly (Duncan's test, $P<0.05$ ).

${ }^{b}$ The root rot index of the negative control is not zero because such young raspberry plantlets occasionally exhibit some necrosis on their basal leaves.

since bacterial growth on mycelium agar resulted in clearing of the opaque medium.

The extracellular proteins produced by strain EF-14 after 48 h of contact with sterilized mycelium of $P$. fragariae var. rubi ML200 were separated by size-exclusion chromatography on Sephacryl S-100 (Fig. 1) to estimate the number of glucanases produced by this strain. Three peaks of $\beta$-1,4-glucanase and one peak of $\beta$-1,6-glucanase activity were detected. A second very weak peak of $\beta$-1,6-glucanolytic activity was found in fractions 42 to 44 . Two peaks of $\beta$-1,3-glucanase activity were found; they may correspond, however, to at least three or even four different molecular species, considering their asymmetric shape.

The lytic character of the glucanases was tested on yeast cell walls and on live Phytophthora cells. The lytic activity in various chromatographic fractions was estimated semiquantitatively by the turbidometric test, with yeast cell walls as the substrate. Peaks of turbidometric activity were found in fractions 25 and 26, 31, and 37 and 38 (data not shown). They did not coincide

TABLE 3. Glucanolytic activities of actinomycete strains grown on different glucan sources ${ }^{a}$

\begin{tabular}{lccc}
\hline \multirow{2}{*}{ Strain } & \multicolumn{3}{c}{ Activity $(\mathrm{U} / \mathrm{ml})$} \\
\cline { 2 - 4 } & $\beta$-1,3-Glucanase & $\beta$-1,4-Glucanase & $\beta$-1,6-Glucanase \\
\hline EF-14 & 0.339 & 0.350 & 0.109 \\
EF-22 & 0.067 & 0.009 & 0.072 \\
EF-25 & 0.284 & 0.001 & 0.075 \\
EF-27 & 0.365 & 0.006 & 0.071 \\
EF-34 & 0.015 & 0.015 & 0.087 \\
EF-43 & 0.110 & 0.027 & 0.083 \\
EF-72 & 0.461 & 0.018 & 0.085 \\
EF-76 & 1.128 & 0.002 & 0.072 \\
EF-97 & 0.224 & 0.023 & 0.083 \\
DVD1 & 1.108 & 0.014 & 0.077 \\
DVD3 & 1.901 & 0.006 & 0.073 \\
DVD4 & 2.085 & 0.001 & 0.075 \\
N106 & 1.821 & 0.003 & 0.078 \\
\hline
\end{tabular}

${ }^{a}$ Bacteria were grown for 7 days in the presence of laminarin or cellulose or for 4 days in the presence of pustulan as the sole carbon source to assay $\beta-1,3-$, $\beta-1,4$, and $\beta-1,6$-glucanase activity, respectively.

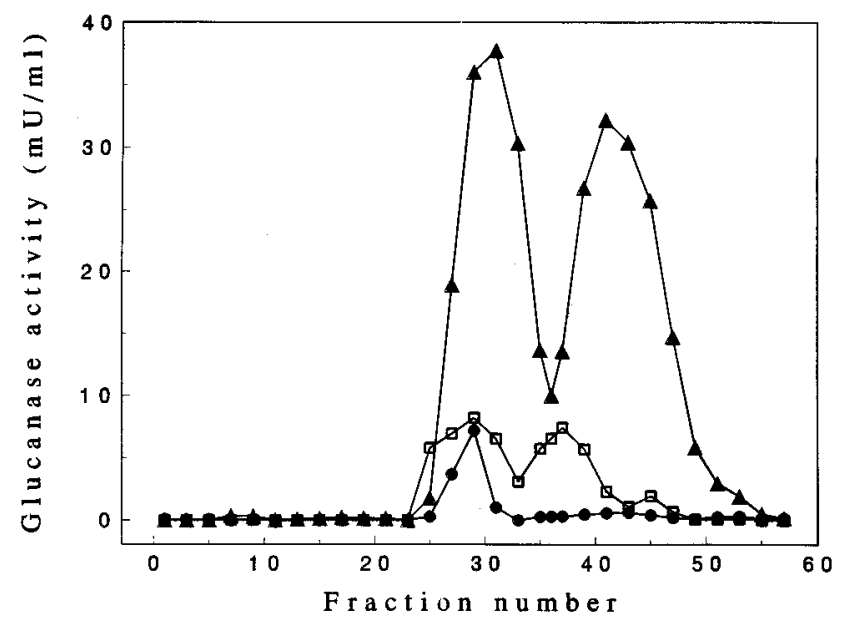

FIG. 1. Size-exclusion chromatographic profile of $\beta-1,3-(\boldsymbol{\Lambda}), \beta-1,4-(\square)$, and $\beta$-1,6-glucanolytic $(\mathbf{)})$ activities from a culture supernatant of strain EF-14 grown in the presence of fragmented Phytophthora mycelium.

with a single peak of glucanase activity, suggesting that the lysis of yeast cell walls is the result of cooperation between different enzymes. The enzymes contained in the culture fluid of strain EF-14 were also shown to exert lytic activity on living mycelium of $P$. fragariae var. rubi ML200 (Fig. 2). Fungal mycelium lysis increased with increasing concentrations of $\beta$-1,3-glucanase. The culture fluid of strain EF-14 lost its lytic properties after being boiled for $10 \mathrm{~min}$. This lytic activity could not be attributed to antibiotics present in the supernatant because even after intensive dialysis, this supernatant retained its full lytic activity.

\section{DISCUSSION}

Several mechanisms by which biocontrol agents reduce plant diseases have been proposed. These mechanisms include production of antibiotics and toxic products (14), secretion of hydrolytic enzymes $(10,23)$, production of siderophores (31), and niche exclusion (44). Screening for biocontrol agents often relies on one criterion, such as inhibition of pathogen growth or parasitism of pathogen structures. In this report, the antagonistic microbes were simultaneously selected for two traits often associated with biocontrol agents, the ability to hydrolyze the cell walls of the pathogen and the production of metabolites active against Phytophthora spp. Thirteen actinomycete strains exhibited both properties and were considered antagonistic to Phytophthora spp. All of the antagonistic strains except N106 belong to the genus Streptomyces (unpublished data); strain N106 belongs to the genus Nocardioides (25).

Antibiotic production has often been associated with the biocontrol ability of actinomycetes (11). In this study, we showed that a high proportion (72\%) of the actinomycetes inhibiting Phytophthora growth by producing antifungal metabolites also secreted glucanases active on Phytophthora cell walls. Even though most actinomycetes secrete chitinases, glucanases, or other extracellular hydrolases, no correlation has been established between production of hydrolytic enzymes and the biocontrol ability of actinomycetes. However, a correlation between enzyme production and the ability to suppress plant disease has been suggested for another biocontrol agent by Chernin et al. (10), who showed, using a gram-negative biocontrol agent, Enterobacter agglomerans, that its ability to protect plants against diseases caused by Rhizoctonia solani, a fun- 

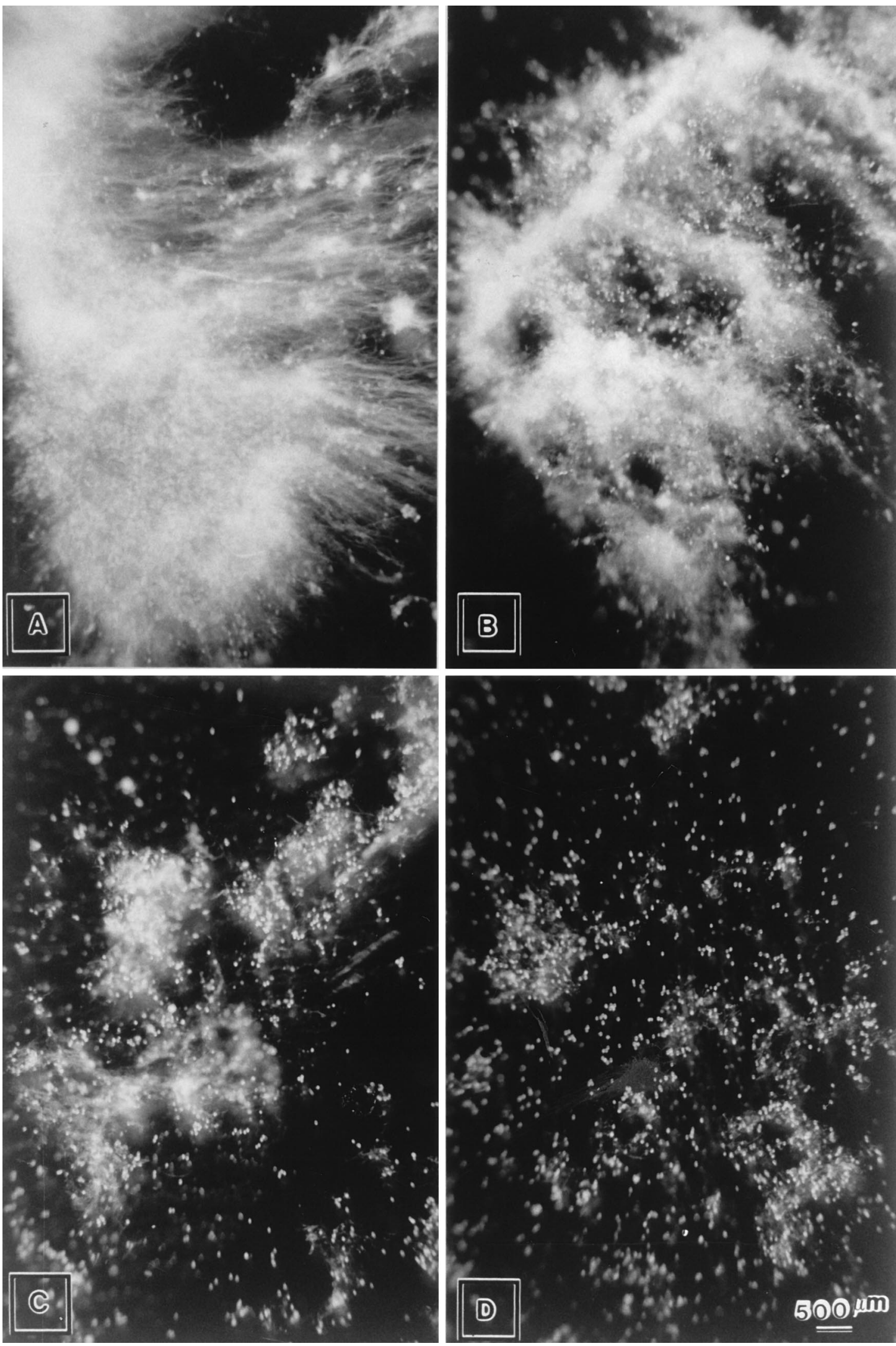

FIG. 2. Micrograph of Phytophthora mycelium incubated at $22^{\circ} \mathrm{C}$ for $150 \mathrm{~min}$ in the absence (A) or in the presence of crude enzyme extracts having 1.5 (B), 3.0 (C), or 6.0 (D) $\mathrm{U}$ of $\beta$-1,3-glucanase activity per $\mathrm{ml}$. 
gus with chitinous cell walls, was lost by making it defective in chitinase production.

In the present study, biocontrol strains were selected for their ability to produce clearing zones on a medium consisting of fragmented Phytophthora mycelium. Phytophthora cell walls do not contain a significant amount of chitin. Instead, $\beta$-glucans constitute 80 to $90 \%$ of the wall dry weight. Cellulosic $\beta$ glucans generally represent less than $30 \%$ of the Phytophthora wall dry weight, whereas noncellulosic $\beta$-glucans account for more than $60 \%$ of the weight. The noncellulosic glucan is a highly branched $\beta-1,3$-glucan, with $\beta-1,6$ links at the branching residues (3). The antagonistic actinomycetes that produced clearing zones on mycelium agar were shown to produce glucanases cleaving $\beta-1,3, \beta-1,4$, and $\beta-1,6$ links. Moreover, separation of glucanases by size-exclusion chromatography suggests that more than one enzyme or enzyme form is associated with each type of glucanolytic activity. The antagonistic actinomycetes thus possess a battery of enzymes which potentially allow very effective lysis of Phytophthora cell walls. These glucanases hydrolyzed other glucan-containing substrates, such as yeast cell walls, laminarin, pustulan, and cellulose. Furthermore, they were also proved to be active on live Phytophthora mycelium, which they lysed in the absence of any antibiotic activity, indicating that they might play a significant role in plant disease suppression.

No direct correlation between the level of glucanolytic activity and the ability of a specific strain to reduce the root rot index was established. However, one should consider that glucanolytic activity was estimated in liquid cultures with a purified substrate such as cellulose, pustulan, or laminarin. The ability of the antagonistic strains to degrade Phytophthora cell wall in soil does not necessarily reflect hydrolysis ability on purified glucan substrates in liquid cultures.

It has been reported previously that actinomycetes produce extracellular $\beta$-1,3- and $\beta$-1,4-glucanases $(5,15)$. However, this is the first report describing $\beta-1,6$-glucanase activities associated with actinomycetes. Indeed, few microorganisms have been characterized as producers of $\beta-1,6$-glucanase $(1,34)$. Rombouts et al. (34) showed that $\beta$-1,6-glucanases played a crucial role in the lysis of yeast cells. This enzyme, by debranching the glucan frame, could facilitate the lysis of Phytophthora cell walls. The levels of $\beta$-1,6-glucanolytic activity in the antagonistic actinomycetes growing on pustulan corresponded to those associated with other $\beta$-1,6-glucanolytic microorganisms (34).

In this study, we established that the production of fungal metabolites and the ability to degrade Phytophthora cell walls are good markers for the selection of biocontrol actinomycetes. Possibly, secretion of enzymes and production of antifungal metabolites interact synergistically in disease suppression mechanisms. For example, antifungal metabolites could prevent Phytophthora growth and impair its defense mechanisms, while glucanases, by degrading Phytophthora cell walls, would contribute to pathogen cell lysis and also supply additional nutrients to the antagonistic population. Further studies are in progress to determine the role of glucanase production and antifungal activity in root rot suppression on raspberry.

\section{ACKNOWLEDGMENTS}

This work was supported by a grant from the Conseil des recherches en pêches et en agro-alimentaire du Québec.

We thank G. Grondin for the work in microscopy and D. LeBel for a critical reading of the manuscript.

\section{REFERENCES}

1. Aano, K., M. Hamura, M. Yamamoto, and T. Asano. 1995. Isolation of extracellular 28-and 42-kilodalton $\beta$-1,3-glucanases and comparison of three ß-1,3-glucanases produced by Bacillus circulans IAM1165. Appl. Environ. Microbiol. 61:122-129.

2. Atlas, R. M., and R. Bartha. 1993. Microbial ecology: fundamentals and applications, 3rd ed. The Benjamin/Cummings Publishing Co., Redwood City, Calif.

3. Bartnicki-Garcia, S., and M. C. Wang. 1983. Biochemical aspects of morphogenesis in Phytophthora, p. 121-137. In D. C. Erwin, S. Bartnicki-Garcia, and P. H. Tsao (ed.), Phytophthora: its biology, taxonomy, ecology, and pathology. APS Press, St. Paul, Minn.

4. Benson, D. R., and W. B. Silvester. 1993. Biology of Frankia strains, actinomycete symbionts of actinorhizal plants. Microbiol. Rev. 57:293-319.

5. Bielecki, S., and E. Galas. 1991. Microbial $\beta$-glucanases different from cellulases. Crit. Rev. Biotechnol. 10:275-304.

6. Bolton, A. T. 1978. Effects of amending soilless growing mixtures with soil containing antagonistic organisms on root rot and black leg of geranium (Pelargonium hortorum) caused by Pythium spendens. Can. J. Plant Sci. 58: 379-383.

7. Bolton, A. T. 1980. Control of Pythium aphanidermatum in poinsettia in a soilless culture by Trichoderma viride and a Streptomyces sp. Can. J. Plant Pathol. 2:93-95.

8. Broadbent, P., K. F. Baker, and Y. Waterworth. 1971. Bacteria and actinomycetes antagonistic to fungal root pathogens in Australian soils. Aust. J. Biol. Sci. 24:925-944.

9. Chattopadhyay, S. K., and B. Nandi. 1982. Inhibition of Helminthosporium oryzae and Alternaria solani by Streptomyces longisporus (Krasil'nokov) Waksman. Plant Soil 69:171-175.

10. Chernin, L., Z. Ismailov, S. Haran, and I. Chet. 1995. Chitinolytic Enterobacter agglomerans antagonistic to fungal plant pathogens. Appl. Environ. Microbiol. 61:1720-1726.

11. Crawford, D. L., J. M. Lynch, J. M. Whipps, and M. A. Ousley. 1993. Isolation and characterization of actinomycete antagonists of a fungal root pathogen. Appl. Environ. Microbiol. 59:3899-3905.

12. Duncan, J. M., D. M. Kennedy, and E. Seemüller. 1987. Identities and pathogenicity of Phytophthora spp. causing root rot of red raspberry. Plant Pathol. 36:276-289.

13. Filnow, A. B., and J. L. Lockwood. 1985. Evaluation of several actinomycetes and the fungus Hypochytrium catenoides as biocontrol agents of Phytophthora root rot of soybean. Plant Dis. 69:1033-1036.

14. Fravel, D. R. 1988. Role of antibiosis in the biocontrol of plant diseases. Annu. Rev. Phytopathol. 26:75-91.

15. Gilbert, M., R. Morosoli, F. Schareck, and D. Kluepfel. 1995. Production and secretion of proteins by streptomycetes. Crit. Rev. Biotechnol. 15:13-39.

16. Hopwood, D. A., M. J. Bibb, K. F. Chater, T. Kieser, C. J. Bruton, H. M. Kieser, D. J. Lydiate, C. P. Smith, J. M. Ward, and H. Schrempf. 1985. Genetic manipulation of Streptomyces: a laboratory manual. The John Innes Foundation, Norwich, United Kingdom.

17. Hussain, S., A. Ghaffar, and M. Aslam. 1990. Biological control of Macrophomina phaseolina charcoal rot of sunflower and mung bean. J. Phytopathol. 130:157-160.

18. King, R. B., C. H. Lawrence, and M. C. Clark. 1991. Correlation of phytotoxin production with pathogenicity of Streptomyces scabies isolates from scab infected potato tubers. Am. Potato J. 68:675-680.

19. Knauss, J. S. 1976. In vitro antagonistic activity of several Streptomyces spp. against species of Pythium and Phytophthora. Plant Dis. Rep. 60:846-850.

20. Lahdenperä, M.-L., E. Simon, and J. Uoti. 1991. Mycostop-a novel biofungicide based on Streptomyces bacteria, p. 258-263. In A. B. R. Beemster, G. J. Bollen, M. Gerlach, M. A. Ruissen, B. Schippers, and R. A. Tempel (ed.), Biotic interactions and soil-borne diseases; proceedings of the 1st Conference of the European Foundation for Plant Pathology. Elsevier, Amsterdam.

21. Latorre, B. A., and R. Munoz. 1993. Root rot of red raspberry caused by Phytophthora citricola and Phytophthora citrophthora in Chile. Plant Dis. 77: 715-718.

22. Locci, R. 1994. Actinomycetes as plant pathogens. Eur. J. Plant Pathol. 100: 179-200.

23. Lorito, M., G. E. Harman, C. K. Hayes, R. M. Broadway, A. Tronsmo, S. L. Woo, and A. Di Pietro. 1993. Chitinolytic enzymes produced by Trichoderma harzianum: antifungal activity of purified endochitinases and chitobiosidase. Phytopathology 83:302-307.

24. Malajczuk, N. 1983. Microbial antagonism to Phytophthora, p. 197-218. In D. C. Erwin, S. Bartnicki-Garcia, and P. H. Tsao (ed.), Phytophthora: its biology, taxonomy, ecology and pathology. APS Press, St. Paul, Minn.

25. Masson, J.-Y., I. Boucher, W. A. Neugebauer, D. Ramotar, and R. Brzezinski. 1995. A new chitosanase gene from a Nocardioides $\mathrm{sp}$. is a third member of glycosyl hydrolase family 46. Microbiology 141:2629-2635.

26. Merriman, P. R., R. D. Price, and K. F. Price. 1974. The effect of inoculation of seed with antagonists of Rhizoctonia solani on the growth of the wheat. Aust. J. Agric. Res. 25:213-218.

27. Montgomerie, I. G., and D. M. Kennedy. 1991. The pathogenicity of Phytophthora species to red raspberry. Acta Hortic. 112:167-176.

28. Neugebauer, E., B. Gamache, C. V. Déry, and R. Brzezinski. 1991. Chitinolytic properties of Streptomyces lividans. Arch. Microbiol. 156:192-197.

29. Nickerson, N. L. 1990. Metalaxyl-resistant strains of Phytophthora fragariae in 
Nova Scotia. Strawberry newsletter no. 4. Department of Agriculture and Marketing, Nova Scotia, Canada.

30. Nourrisseau, G., and A. Baudry. 1987. Un Phytophthora cause de dépérissement du framboisier en France. Phytoma 394:26-32.

31. O'Sullivan, D. J., and F. O'Gara. 1992. Traits of fluorescent Pseudomonas spp. involved in suppression of plant root pathogens. Microbiol. Rev. 56:662-676.

32. Pridham, T. G., P. Anderson, C. Foley, L. A. Lindenfelser, C. W. Hessetime, and R. G. Benedict. 1956-1957. A selection of media for maintenance and taxonomic study of streptomycetes. Antibiot. Annu. 1956-1957:947-953.

33. Ribiero, O. K. 1978. A source book of the genus Phytophthora. J. Cramer, Lehre, Germany.

34. Rombouts, F. M., G. H. Fleet, D. J. Manners, and H. J. Phaff. 1978. Lysis of yeast cell walls: nonlytic and lytic (1-6)- $\beta$-D-glucanases from Bacillus circulans WL-12. Carbohydr. Res. 64:237-249.

35. Rothrock, C. S., and D. Gottlieb. 1984. Role of antibiosis in antagonism of Streptomyces hygroscopicus var geldanus to Rhizoctonia solani in soil. Can. J. Microbiol. 30:1440-1447.

36. Sabaou, N., and N. Bounaga. 1987. Actinomycètes parasites de champignons: étude des espèces, spécificité de l'action parasitaire au genre Fusarium et antagonisme dans le sol envers le Fusarium oxysporium F. sp. albedinis (Killian et Marie) Gordon. Can. J. Microbiol. 33:445-451.

37. Spiro, R. G. 1966. The Nelson-Somogyi copper reduction method. Methods Enzymol. 8:7-9.

38. Sutherland, E. D., and G. C. Papavizas. 1991. Evaluation of oospore hyperparasites for the control of Phytophthora crown rot of pepper. J. Phytopathol. 131:33-39.

39. Tanaka, Y., and S. Omura. 1993. Agroactive compounds of microbial origin. Annu. Rev. Microbiol. 47:57-87.
40. Thibodeau, P. O. 1991. Le pourridié (Phytophthora) du framboisier s'est installé au Québec, p. 15-24. In Colloque sur la framboise "point sur la culture." Conseil des Productions Végétales du Québec, Bibliothèque Nationale du Québec, Quebec, Canada.

41. Turhan, G., and K. Turhan. 1989. Suppression of damping-off on pepper caused by Pythium ultimum Trow and Rhizoctonia solani Kühn by some new antagonists in comparison with Trichoderma harzianun Rifai. J. Phytopathol. 126: $175-182$.

42. Wadi, J. A., and G. G. Easton. 1985 . Control of Verticillium dahliae by coating seed pieces with antagonistic bacteria, p. 134-136. In C. A. Parker, A. D. Rovira, K. J. Moore, P. T. W. Wong, and J. F. Kollmorgen (ed.), Ecology and management of soilborne pathogens. American Phytopathology Society, St. Paul, Minn

43. Washington, W. S. 1988. Phytophthora cryptogea as a cause of root rot of raspberry in Australia: resistance of raspberry cultivars and control by fungicides. Plant Pathol. 37:225-230.

44. Weller, D. M. 1988. Biological control of soilborne pathogens in the rhizosphere with bacteria. Annu. Rev. Phytopathol. 26:379-407.

45. Wilcox, W. F. 1989. Identity, virulence and isolation frequency of seven Phytophthora spp. causing root rot of raspberry in New York. Phytopathology 79:93-101.

46. Yin, S. Y., J. K. Chang, and P. C. Xun. 1965. Studies in the mechanisms of antagonistic fertilizer "5406." IV. The distribution of the antagonist in soil and its influence on the rhizosphere. Acta Microbiol. Sin. 11:259-288.

47. Yuan, W. M., and D. L. Crawford. 1995. Characterization of Streptomyces lydicus WYEC108 as a potential biocontrol agent against fungal root and seed rots. Appl. Environ. Microbiol. 61:3119-3128. 